\title{
Japanese Educators' Movement Experiences - Transformation of Research and Education as Seen from Life Story Research-
}

\author{
Y Sugimura \\ University of Miyazaki, Japan \\ \{sugimurayoshi@cc.miyazaki-u.ac.jp\}
}

\begin{abstract}
The number of foreign students moving to Japan from abroad has increased. At the same time, there are many Japanese language teachers who move around the world. Not only foreign students, Japanese language educators also experience migration for various reasons such as domestic transfer, overseas movement, and returning back to Japan. Therefore, this research will clarify what kind of things can be specifically mentioned as the influence of the movement of Japanese language teachers on research and education. Also, it will clarify the process of change of the influence and "the relationship between research, education and movement" in time series. By clarifying the narrative experienced by the moved teacher, sharing the influence on the new affiliation organization, the viewpoint of the research and the contribution to the practical education, and so on, it is possible to know the transformation of Japanese language educators' research anf educaion. In addition, we aim for a multicultural Japanese society that is becoming more complex and diversifying daily by obtaining narratives on how research and education are affecting the difficulties, historical backgrounds and social norms that are hidden in the movement, and is also possible to send out various messages. Then, it can be decided to clarify the transformation process and importance of research and education that "the influence of migration" can make recommendations to the Japanese language education world in the future.
\end{abstract}

Keyword: Life Story, Narrative, Qualitative Research, Research And Education Change, Japanese Language Education

\section{INTRODUCTION}

The purpose of this research is to clarify how the movement of Japanese language teachers at their home country as well as abroad affects the perspective of research and education, and to clarify the change of research and education that the influence has brought. In Japan, as of the end of March 2019, the program to accept 300,000 foreign students has also been achieved, and not only the number of foreign students moving to Japan is increasing but at the same time, there are many Japanese language teachers who move around the world for various reasons.

It is not possible to rely solely on ordinary research achievements and oral presentations to understand the impact and transformation process of the movement. It is necessary to have a new "narrative" that has never been revealed. Therefore, in this research, we adopt qualitative 
research methods of life story and pay attention to "movement of Japanese language educators" and see from the viewpoint of humanity, overseas experience, reflection, growth and experience of teacher to narrate "viewpoint of research and education and its transformation". The interviewee is a Japanese language educator who has experienced multiple movements so far, has a perspective on research and education and its transformation, who narrated his own experience and made clear about impact and transformation process of the movement.

Moreover, another aim of this paper is, although the author also experienced the movement inside and ouside Japan, the writer felt the need to respond flexibly to the new environment appropriately each time. It can be said as a turning point of life where one got a lot of learning, but at the same time also experienced different cultural experiences, differences, and difficulties in relationships. Japanese language educators, like foreign students, have "movements" and experience various things in the new environment. In particular, in recent years, it is not common to say that there are not many cases in which the same affiliation institution reaches the retirement age, and it is certain from their own experience that travel experience has affected research and education, affiliation institutions and colleagues.

Life story research in Japan is actively conducted in the sociology domain represented by Nakano (1977, 2002), Yamada (2007), Sakurai (2002, 2005, 2012) and Kobayashi (2005). In addition, life story research for school teachers is also carried out in Western countries as well as in Japan by Takaira $(1994,1996)$ et al. And, even in the Japanese language education world, especially in the 2000 's, there are many research methods of the Japanese language education scholars, such as Kawakami $(2010,2011,2015)$, Sandai (2009 a, 2013, 2014, 2015) and so on. It has been adopted and widely implemented for younger students and foreign students. Furthermore, when it comes to life story research for Japanese language educators, Pang and Eguchi (2003), Eguchi (2008), Iino (2009, 2010, 2011, 2012a, 2012b, 2015, 2017), conducted actively, but the number of studies is only a few.

Kawakami (2011) uses the term "youth's movement" in life story research for foreign students, and advocates a new concept of distance from foreign students' Japanese language. Iino (2017) associates the change brought by "teachers' movement" with "change in the position of educational practice", "change in the practice community", "interaction/dialogue with other people" and so on. However, life story research itself in the relation between teacher's movement and research has not been conducted yet. In addition, it has not been very clear how the teacher's movement experience affects the position as a researcher and educator.

Iino (2017) talks about movement and teaching practice as a change in the position of teaching practice that views the growth of Japanese language teachers from life stories. It is stated that the movement of teachers from the initial position of Japanese language teachers will bring about a change in the position of teaching practice. The process of change is developed with five teachers as an example, and it can be seen that teacher's movement between educational institutions is considered to be movement between practical communities. It also points out that developmental transformation of the practical community formed by teachers is born. Furthermore, it mentioned that changes in the teacher's own position, which is an understanding of the position in practice, examination, changes, also appear in the view of learning, the purpose of teaching practice, and so on, caused by the interaction and dialogue with another party. After that, by defining the teacher's own change as an identity and making the teacher's identity negotiation and awareness by association with the community, it is linked to the development of the teacher himself, the Japanese language education, and brings about growth not only to the Professor As an individu. However, Iino develops life stories from the perspective of "Japanese language teachers and practical education", and does not observe the movements of teachers in the concept or perspective such as "Japanese language education and 
research". From the viewpoint of Japanese language education in universities, it is realistic that researcher $=$ educator, and generally the same person practices research and education. Therefore, in this research, a large category of "research" is added to teacher's movement and education, and the research target is narrowed down to one Japanese language educator, the narrative is developed, and the influence of the movement on the research is clarified.

Professor A is a Japanese man, to whom the writer has been very grateful for the past four years. An experienced Japanese educator in his 70 s with a title of 30 years teaching Japanese language in Japan as well as overseas. In this paper, Professor A's life was classified into 4 classes: 1) Study Abroad Period, 2) Education Period, 3) Research Education Period, and 4) Teacher Training Period. Furthermore, the research period was set to 1, 2, 3, 4 in the subclassification.

Table 1 : Professor A's Biography and supplementary information

\begin{tabular}{|c|c|c|c|c|c|}
\hline Period & Occupation & $\begin{array}{c}\text { Research } \\
\text { period }\end{array}$ & $\begin{array}{l}\text { No. of } \\
\text { Years }\end{array}$ & Information & $\begin{array}{c}\text { Additional } \\
\text { position }\end{array}$ \\
\hline \multirow[b]{2}{*}{$\begin{array}{l}\text { (1) Study } \\
\text { abroad }\end{array}$} & Student & - & 4 & $\begin{array}{l}\text { Left hometown to a } \\
\text { metropolitan area as } \\
\text { a student of social } \\
\text { science in a } \\
\text { Japanese university. } \\
\text { Met foreign } \\
\text { students and } \\
\text { actively carry out } \\
\text { international } \\
\text { exchanges such as } \\
\text { language exchange. }\end{array}$ & - \\
\hline & $\begin{array}{c}\text { Foreign } \\
\text { student } / \\
\text { TA }\end{array}$ & - & 9 & $\begin{array}{l}\text { Study abroad in } \\
\text { English-speaking } \\
\text { "country A" with } \\
\text { the inter-university } \\
\text { exchange program. } \\
\text { Studied psychology } \\
\text { and linguistics and } \\
\text { moved to three } \\
\text { cities and three } \\
\text { universities (A, B, } \\
\text { C). Took charge of } \\
\text { Japanese language } \\
\text { related classes, was } \\
\text { accepted as a } \\
\text { foreign student, and } \\
\text { worked as a } \\
\text { teaching assistant } \\
\text { (TA) as an }\end{array}$ & - \\
\hline
\end{tabular}




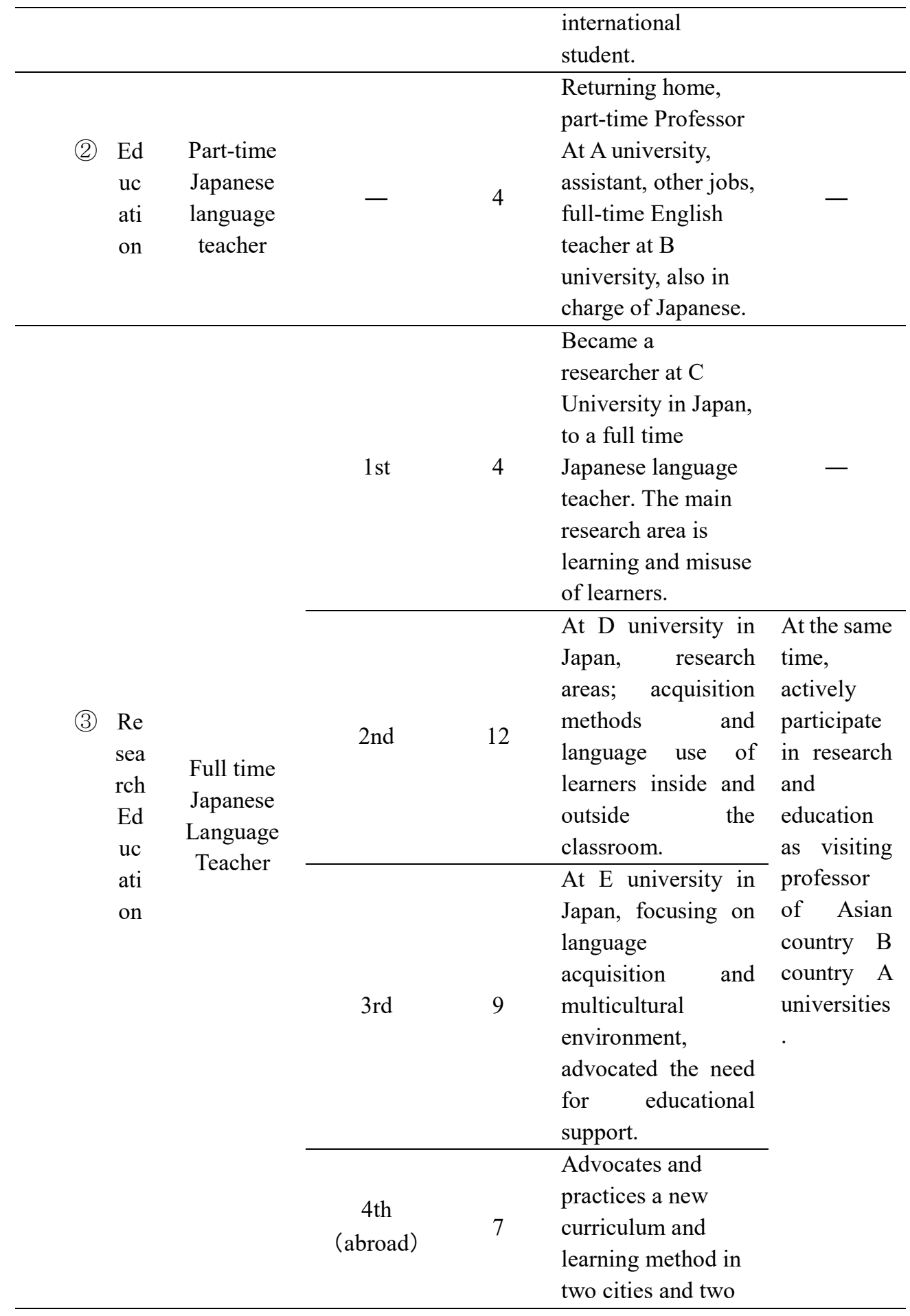




\begin{tabular}{|c|c|c|c|c|c|}
\hline & & & & $\begin{array}{l}\text { universities }(\mathrm{B}, \mathrm{C}) \\
\text { in Asian "country } \\
\text { B". }\end{array}$ & \\
\hline $\begin{array}{l}\text { (4) Teacher } \\
\text { Training }\end{array}$ & $\begin{array}{c}\text { Training } \\
\text { course } \\
\text { representati } \\
\text { ve }\end{array}$ & - & $\begin{array}{l}\text { Ongoin } \\
\mathrm{g}\end{array}$ & $\begin{array}{l}\text { Returning home, } \\
\text { based E-University } \\
\text { In Japan, active } \\
\text { mainly in Japanese } \\
\text { language teacher } \\
\text { training. }\end{array}$ & - \\
\hline
\end{tabular}

\section{RESEARCH METHOD}

\subsection{Professor A's Notice}

Earned before the interview, it can be considered as one of the factors that influence the formation of Professor A as an educator. From an early age, more than half relatives around were educators, but no memory in particular and parents didn't teach strongly about education. On the other hand, he is said to be a very active student who was very good at studying and always had the best leadership in his class. If we come across alumnis in recent years, he is often adressed as "A the genius", Professor A himself seems to be not aware about this, but his surroundings recognize him as genius.

\subsection{Interview Method}

Carried out 3 times in total, the first and the second was about 120 minutes, the third for approximately 60 minutes. The interviews were conducted in the wrier's laboratory to ensure privacy, a quiet environment, and a relaxed and talkable environment while drinking tea. Also, prior to the interview, interview purpose and six questions were explained in advance verbally, written in a document, then sent by e-mail. As a result, the purpose of the interview was clear, the writer was able to smoothly cooperate with the recording permission and the research agreement. The interviews were conducted semi-structured as prior questions were set. Also, on the day of the interview, Professor A prepared carefully about his own narrative, went from the past to the present, took events and experiences on a chronological flow, and spoke fluently.

\subsection{Analysis Method: Life Story Research}

This research needs understanding and interpreting the movement background, teachers' ideology, research motives, research background, methods of reducing research results, methods of use, methods of learning, teaching methods, methods of teaching, and the relationship with teaching practice. And above all, it is important to see the change in humanity that the teacher's movement has exerted. Therefore, qualitative research methods are needed, and it was judged that it would be best to adopt life story research method. By using the life story research method, various questions in Japanese language education have become clear, and valuable data are beginning to be accumulated. Accumulation of such data serves as a proposal for the Japanese language education community in general, educational items related to new Japanese language teacher training, teaching methods, coaching methods, class contents, and influences research as well. Interviews and narratives are valuable living materials. 


\section{RESULT AND DISCUSSION}

Due to character limitation, dialogue between the writer and Professor A will not be written in this paper. Instead, explanation from the narration of Professor A will be given.

\section{1 (1) Study Abroad Period as Foreign Student / Deputy Teacher: From Minority to Majority}

In order to develop his own future path, Professor A experienced the hardship of such a time when his home school didn't have a study abroad system when he was a student, so he built up his own system and advanced to overseas, experienced the so-called first overseas transfer.There, in the 1970s, Professor A experienced racial problems of majority and minority, which he had never felt before. It was also a time when he has taken the first step as a Japanese language educator, as well as an important time that leads to the formation of the philosophy and philosophy of later education.

After all, Professor A in his twenties moved to three cities (A, B, C) in Country A for almost nine years during the 1970s and early 80's, enrolled in bachelor's, master's, and doctoral courses, and studied psychology, Japanese, and English. However, as a TA (teaching assistant), it was an opportunity for teachers to go into the practice of Japanese language education. In other words, it is the birth of a Japanese language teacher led by the overseas movement of the teacher. There is also a time in which he experienced various cross-cultural societies in terms of life and gain a glimpse of the diversity of races. Continuing, Profesor A sees a multicultural society in the "city C" of Country A.

The roots of multilingual and multiculturalism, which is the research area of Prof. A later, probably prove to this experience that was cultivated in his 20's. And it turns out that it is related with the research item mentioned later that it was influenced by subsequent research. It was also found as a valuable time which created viewpoint of the research and the method of returning the research results as the basics of multilingual culture, that is becoming the philosophy of Professor A, who feel from both viewpoints of Professor And learner while being student / Japanese TA position.

\subsubsection{Education period: New Part-time Japanese Language Teacher, Encounter with Former Teacher, Fight Against Social Norms}

While studying abroad in City B at University B, Mr. Yamada (a pseudonym) who is Professor A's former teacher recommended him to study abroad in the third place, City C University $\mathrm{C}$. However, while studying abroad at $\mathrm{C}$ university, he was urged to return home and work for a Japanese university. He has been active for nearly 10 years while having multiple jobs as a part-time lecturer in English, Japanese, and other jobs. Here, the writer would like to focus on the relationship with the former teacher that is the turning point. In addition, we can see the conflict with the monoculturalism of Japanese society and the norms of society in the 1980 s after returning home. It is time to read the connection with society in such movement, the humanity in the personality of Professor A, the strength to some kind and the research attitude. It can be seen that Japanese society in the 1970s and 80s was a period of poor respect for the originality and individuality, judging humanity by appearance. Under such a background of the 
times, the humanity of the Professor A who respects his teacher can be seen without giving down the invitation of the Professor As a language lecturer. However, in exchange for that, he experienced the suffering of conflict and cross-cultural understanding that bends for life. Discrimination and reverse-culture shock, such experiences will construct the attitude and research attitude towards the Japanese language education of Professor A later. Here you can feel the researcher's soul and the essence of Professor A. He seems to have a good sense in reading the trend of the times. He analyzed the situation calmly and read the needs of the times. This leads to misuse analysis, which is the first research phase of the next 4.3(3) Research Education Period.

\section{2 (3) Research Education Period. 1st Research: Full-time Japanese University Language Teacher, Language Acquisition and Analysis of Misuse}

Through the experience of teaching Japanese as a full-time lecturer at A university and a full-time English lecturer at B university, Professor A selected the way of becoming a full-time Japanese lecturer as a researcher by the appearance of his former Professor Again. It seems that the exchange, the process, and the respect for the teacher have made Professor A make a decision. At his 40's, Professor A was in charge of research and educational activities as his first full-time Japanese language lecturer carrier. He explored research motives, and the experience gained from the movement was utilized there, where the importance of research and the hints of language acquisition that could be felt from the educational scene were hidden.

As a result of focusing on the language acquisition in the short term of the learner on the educational field where Professor A feels by himself, misuse analysis that was not focused much at that time in Japanese language education was started and attracted attention. By taking advantage of the ESL education that he learned while studying abroad (at University B in Country A), he incorporated experience of other fields into Japanese language education. The fact that the experience of moving abroad started research that was applied to domestic Japanese language education in reverse movement mode is also a result that could be achieved from the experience.

The writer could understand that Professor A is a Japanese language teacher who has both educational practice and research activities. In addition, practical research that incorporates experiences from other fields is carried out, and it is important for other Japanese language teachers to make experience in different fields, experience abroad, and attribute "movement". It becomes clear that it can be a hidden keyword.

\section{3 (3) Research Education Period. 2nd Research: From Second Language Acquisition to Nature Acquisition Theory}

After that, Professor A is appreciated for language acquisition research and misuse analysis research, and positioned at D University in the ciy center. The target of research shifts from language acquisition and misuse analysis to second language acquisition, and is launched to the academic society. It is a universal thing, and it is also the start of a research group that has made a great contribution to Japanese language education. Even in new places where change is taking 
place, cross-cultural experiences in overseas experiences, and experiences of majority and minority cultures are also very useful for research. After all, he has been at D University for more than 10 years, and will form the foundation of multilingual cultural education.

From this time on, Professor A particularly places importance on the learner's point of view, respect, and reduction and feedback of research data. This is consistent with his philosophy as a teacher. With the environment of the city center, the increase of foreign residents in the background of the 1990s, nature and the environment outside the classroom, he realized that in fact his experiences when moving to Country A is actually occurring in Japan. In a sense, we are experiencing social change and acceptance change. Also many foreign residents are "Japanese users" who live using Japanese, not for learning Japanese, made Professor A shifted his research object to the natural acquisition of language outside the classroom.

It is a transition period in which the research object was shifted to minority Japanese users and non-class Japanese users who exist in the community, with a focus on foreign Japanese users who naturally learn languages. The humanity of Professor A is reflected, and the perspective of the philosophy and research of the educator and consistent researcher can be confirmed.

\section{4 (3) Research Education Period 3rd Research : Multilingual Multicultural Education, The Need for Japanese Language Support Education}

This time coincides with the time when Professor A moved from D University in city center to $\mathrm{E}$ university in a local city. It is also a transformation period of research that new migration produces.

The narrative here shows the transformation of Professor A's research, and the link between natural acquisition of languages and multilingual acquisition. He feels the necessity of the environment to support it, and decided to establish the field of Japanese language support education.

\section{5 (3) Research Education Period 4th Research: To Asia}

After that, in the 2010's, Prof. A taught in Country B, University B and C in Asia for a total of about 6 years. It is said that the move to Country B was a natural flow of the results of working hard at research and education while having the title of visiting professor at Country B University A while working at Japan's D and E universities. It is the first time that this C university is able to curricularize as well as the realization of a revolutionary curriculum for country B. The impact on universities, departments, departments, colleagues, and students given to three universities (A, B, C) in country B is extremely large, and the achievements of Professor A are immeasurable. "Movement" in the same overseas B country eventually became a curriculum acceptance type that can be called a compilation of research. 


\section{6 (4)Teacher Training Period : Launch of Japanese Language Teacher Training Course, Advice for Japanese Language Education}

After that, Prof. A returned to Japan and started to set up a Japanese language teacher training course based on E university, and received a law bill for accepting foreign personnel starting from September 2019, staying up to 340,000 people in 5 years For the Japanese language teacher training project corresponding to the diversity and diversification of foreigners aimed at, the importance of creating a curriculum and practical education that has made use of the experience of movement has been devoted.

The movement of Professor A has had a strong influence on Japan as well as country B. There is an influence that leads the research trend of society, and many research student guidance and dissertation guidance are performed. In addition, he will take the initiative leadership and share his experienced research methods with his fellow and young researchers, teach methods based on his research philosophy, and the influence also brings change in education. Thanks to the move of the faculty members of the affiliated institutions and related institutions, the development of research generated by the further movement will be continued forever. As for the perspective of movement and education, from ProfessorA's philosophy, which always concerns about the surroundings as well as about the learners, with the learnercentered, it can be understood that he is in contact with the student with as supporter's position. An attitude that has changed from educators to supporters may appear here.

\section{CONCLUSION}

It is the accumulation and sharing of experiences, and the "narrative" of experiences. In this way, it became clear that the "talking" had an influence on the university and community as well as the experience of the Japanese language teacher who was an individual, and also established a position to support Japanese language and a place for education. The changes in research that could not be obtained only by the research achievements of the Japanese language teachers, the ideas for education, etc. were clarified, and as a result, the relationship between the research results and the practical education that the movement had was also clarified. Therefore, it is thought that the narrative in this research obtained from the life story of Professor A that is not usually told is also very useful in teachers' reflection, position and growth. In addition, it was also found that it is important to look at the benefits from the application from other fields, the change of the age, the change of the environment, the idea of education, the attitude of teachers, and the movement effect in the conception and implementation of research. And it turned out that it is possible for the teacher to change in pursuit of continuity without sticking to one research item or field, even if the diversity and times of learners are changing. In this way, life story research has shown that teachers can learn to be flexible by moving, become sensitive to various diversity, and use their corresponding abilities and experiences in research and education.

The experience gained from this research's narrative is also an accurate advice by Prof. A, who advocates the acceptance of multiple languages and multiple cultures, and advocates not only a task that can be completed by only Japanese language education but a major theme of language education. It may be an issue that Japanese language education personnel should listen to in the future through experiences such as domestic and foreign movements, differences in places, times, environments, social backgrounds, and acquisition of a wide variety of languages. Also, it is clear that the teacher's experience of moving is a very meaningful action for learners around the world who want to study in Japan, making the most of the accumulated experience, which is also useful for the learners and teachers. Therefore, it may be desirable to 
introduce a system that incorporates teachers' overseas training more actively, and to further promote short-term programs that can be realized by universities and related institutions.

In this research, the writer narrowed the research target to Professor A who has been active as a Japanese language educator for 40 years, conducted interviews, and obtained narratives using the life story research method. As future tasks, the writer feels an urgency to conduct similar questions for multiple teachers, clarify similarities and differences obtained from them, and conduct more detailed analysis and data collection. In addition, it is expected that research subjects and educational methods will differ depending on the time background and moving places, so interviews with teachers of different nationalities, genders, regions and ages can be done to collect and share more diverse data. Furthermore, how to use the personal information data obtained this time for Japanese language education, and how to accumulate data as research of life story in the Japanese language education field is the issue. It can be said that it is urgently desirable to go beyond the framework of personal research and to discuss not only the Japanese language education field but also other fields and other languages.

\section{REFERENCES}

[1] Iino, R. (2015) Nihongo Kyōiku ni Kōken Suru Kyōshi no Raifusutōrī Kenkyū to wa. Sandai Junpei (ed.). Nihongo Kyōiku-Gaku To Shite No Raifusutōrī Katari O Kiki, Kaku To Iu Koto. (pp.248-273). Tōkyō: Kuroshio.

[2] Iino, R. (2017) Nihongo kyōshi no seichō raifusutōrī kara mitsu kyōiku jissen no tachiba no henka. Tōkyō: Coco.

[3] Eguchi, E. (2008) Nihongo Kyōshi, Yamakawa Saya-San No Raifusutōrī. Kyōto Seika Daigaku Kiyō: 34, 1 - 23.

[4] Kawakami, I.(ed.). (2010) Watashi Mo 'Idō Suru Kodomo'datta - Kotonaru Gengo No Ma De Sodatta Kodomo-Tachi No Raifusutōrī. Tōkyō: Kuroshio.

[5] Kawakami, I. (2011) Idō Suru Kodomo-Tachi' No Kotoba No Kyōiku-Gaku. Tōkyō: Kuroshio.

[6] Kawakami, I. (2015) Anata Wa Raifusutōrī De Nani O Kataru No Ka - Nihongo Kyōiku Ni Okeru Raifusutōrī Kenkyū No Imi. Sandai Junpei (Hen). Nihongo Kyōiku-Gaku To Shite No Raifusutōrī Katari O Kiki, Kaku To Iu Koto (Pp. 24 - 49). Tōkyō: Kuroshio.

[7] Kawakami et al. (2011) "Idō Suru Kodomo-Tachi” Wa Daigaku De Nihongo O Dono Yō Ni Manande Iru Ka - Fukusū Gengo Kankyō De Seichōshita Ryūgakusei Daigakusei No Nihongo Raifusutōrī O Moto Ni'“Waseda Kyōiku Hyōron” :25 (1 ), 57 - 69.

[8] Goodson, I. \& Sikes, P. (2006) Raifuhisutorī No Kyōiku-Gaku — Jissen Kara Hōhō-Ron Made (K. Takaira Trans.). Kyoto: Showado.

[9] Kuno, Y. (2018) Jiko Naisei No Kanten Kara No Raifusutōrī Saidoku Ni Tsuite: Ryūgakusei No Seichō O Sapōto Suru Bijinesu Nihongo Kyōiku Jissen O Mezashite. Hokkaidōdaigaku Daigakuin Kyōiku-Gaku Kenkyū Kiyō: 130, 85 - 90.

[10] Sakurai, A. \& Kobayashi, T. (ed.) (2005) Raifusutōrī Intabyū Shitsuteki Kenkyū Nyūmon. Tōkyō: Serica.

[11] Sakurai, A. (2012) Raifuhisutori-Ron. Tōkyō: Koubundou.

[12] Sakurai, A. \& Ishikawa, R. (ed.) (2017) Raifusutōrī Kenkyū Ni Nanigadekiruka TaiwaTeki Kōchiku Shugi No Hihanteki Keishō. Tōkyō: Sinyosha. 
[13] Takaira, K. (2015) Kyōshi No Raifusutōrī: Kōkō Kyōshi No Chūnen-Ki No Kiki To Saisei. Tōkyō: Keiso-shobo.

[14] Nakano, T. (1977) Kōjutsu No Seikatsu-Shi - Aruon'na No Ai To Noroi No Nihon Kindai Sōsho Raifu Hisutorī 1. Tōkyō: Ochanomizu-shobo.

[15] Nakano, T. \& Sakurai, A. (ed.). (2002) Raifusutōrī no shakai-gaku. Tōkyō: Koubundou.

[16] Pang, J. \& Eguchi, E. (2003) Taiwanjin Nihongo Kyōshi No Raifusutōrī'. Gengo Bunka Gakkai Ronshū: 20, 75 - 93.

[17] Yokomizo, S. (2006) Nihongo Kyōshi Yōsei Kenshū Ni Okeru 'Kyōshi No Raifuhisutorī Kenkyū' No Kanōsei No Tsuikyū. Haruhara, K. \& Yokomizo, S. (ed.) Nihongo Kyōshi No Seichō To Jiko Kenshū — Aratana Kyōshi Kenkyū Sutoratej̄̄ No Kanōsei O Mezashite (pp. 158 - 179. ) Tōkyō: Bonjin-sha.

[18] Sandai, J. (2009) Komyuniti E No Sanka No Jikkan To Iu Nihongo No Manabi Kankokujin Ryūgakusei No Raifusutōrī Chōsa Kara. Waseda Nihongo Kyōiku-gaku 6, 1 14.

[19] Sandai, J. (2013) “Ko No Bunka” Tankyū To Shite No Gengo Bunka Kyōiku Kenkyū — Raifusutōrī Kenkyū To Jissen Kenkyū No Keiken O Tsüjite. "Gengo Bunka Kyōiku Kenkyū" 11,2 - 12.

[20] Sandai, J. (2014) Nihongo Kyōiku To Raifusutōrī Kenkyū No Genzai - Sono Kadai To Kanōsei Ni Tsuite. "Riterashirīzu” 14, 1 - 10.

[21] Sandai, J. (2015) Nihongo Kyōiku-Gaku To Shite No Raifusutōrī O Tou. Sandai, J. (ed.) “Nihongo Kyōiku-Gaku To Shite No Raifusutōrī Katari O Kiki, Kaku To Iu Koto"” (pp. 1 22). Tōkyō: Kuroshio.

[22] Yamada, Y. (2000) Jinsei O Monogataru Koto No Imi - Raifusutōrī No Shinri-Gaku. Yamada, Y. (ed.) “Jinsei O Monogataru - Seisei No Raifusutōr $\vec{\imath}$ ' (pp. 1 - 38). Kyoto: Minerva Shobo.

[23] Yamada, Y. (2005) Raifusutōrī Kenkyū - Intabyū De Katari O Toraeru Hōhō. Akita, K. \& Sato, M. (ed.) Kyōiku Kenkyū No Mesodoroj̄̄ — Gakkō Sanka-Gata Maindo E No Izanai (pp. 191 - 216. ) Tōkyō: Tōkyō Daigaku Shuppankai.

[24] Yamada, Y. (2007) Jinsei O Monogataru Koto No Imi - Raifusutōrī No Shinri-Gaku. Yamada, Y. (ed.) “Jinsei O Monogataru - Seisei No Raifusutōr $\vec{\imath}$ (pp. 1 - 38). Kyoto: Minerva Shobo. 